\title{
11 Comparative assessments and conclusions
}

\author{
Elin Lerum Boasson, Merethe Dotterud Leiren \\ and Jørgen Wettestad
}

\section{Introduction}

In this chapter, we systematically compare the development of renewables support mixes in Germany, the UK, Poland, France, Sweden and Norway, asking: what can explain the differences and similarities across countries and over time? Specifically, why have some countries developed technology-specific mixes, whereas others have focused on technology-neutral mixes? Further, we examine whether our findings are in line with explanations under the multi-field approach, as presented in Chapter 3 of this book. Systematic comparison of developments in four differing time-periods in the six countries enables us to offer answers to the sub-questions that have guided this book - namely, how and to what extent is the development of renewables support mixes affected by:

- the European environment?

- the domestic organizational fields?

- the domestic political fields?

And further: do developments in one field influence developments in others?

We present a range of systematic comparisons, showing that differences and similarities across countries can largely be explained by variance in the state of the domestic political and organizational fields and their differing interrelationship with the wider process of Europeanization. Systematic comparative multifield assessment can offer new insights into the role of political and institutional dynamics for energy and climate transitions, as well as for policy change and stability more generally.

Our comparisons aim at answering the research questions of this book, one question at a time. This chapter draws on all the other chapters of this book but does not go in dialogue with scientific literatures on Europeanization, policy processes or climate transitions. The more general implications for larger scientific discussions on these topics are presented in Chapter 12.

\section{The European environment: spurring variation}

Chapter 2 presented the story of the development of renewables support schemes in Europe. The ensuing case-study chapters have discussed how and to what 
extent renewables support in each country in focus has been influenced by the European environment (see Table 11.1 for a summary of the main findings). We had expected the European environment to dominate the development of domestic renewable energy policies more when vertical Europeanization was strong and when horizontal Europeanization was coherent, in the sense that one specific support-scheme mix had gained superiority (EU governing). While we do find that the European environment is more important for many countries under EU governing conditions, it emerges as generally more important than we expected also under other conditions. Indeed, we find that the actual effect of the European environment depends partly on developments in domestic fields.

The first row in Table 11.1 shows differences in the state of the European environment over time, whereas the following rows describe how (horizontal and/or vertical) and to what extent (grey scale) the European environment has affected the countries. Light grey shading indicates the time-periods where the European environment has influenced the development of domestic support mixes, whether by supporting or by undermining developments in the domestic fields. Influences on small-scale as well as large-scale support schemes are taken into account. Periods when Europeanization processes have been of little importance are marked by a dash, in turn indicating the importance of domestic organizational and/or political fields in shaping policy developments in these periods. Note that the European environment has never been the main driver of changes or stabilities in the domestic support schemes, so there are no periods with dark grey shading.

Horizontal Europeanization refers to the diffusion of ideas, measures or policy designs across countries and fields within the European environment. The more

Table 11.1 Comparing the role of the European environment across time and cases*

\begin{tabular}{|c|c|c|c|c|}
\hline $\begin{array}{l}\text { Period } \\
\text { Country }\end{array}$ & $\begin{array}{l}1999 \text { and } \\
\text { earlier }\end{array}$ & 2000-2004 & 2005-2009 & $2010-2016$ \\
\hline $\begin{array}{l}\text { State of the } \\
\text { European } \\
\text { environment } \\
\text { over time }\end{array}$ & 1000 flowers & $\begin{array}{l}\text { Horizontal } \\
\text { harmonization }\end{array}$ & $\begin{array}{l}\text { Horizontal } \\
\text { harmonization } \\
\text { and (indirect) } \\
\text { EU governing }\end{array}$ & EU governing \\
\hline Germany & - & - & - & $\begin{array}{l}\text { Vertical and } \\
\text { horizontal }\end{array}$ \\
\hline UK & - & - & $\begin{array}{l}\text { Vertical and } \\
\text { horizontal }\end{array}$ & $\begin{array}{l}\text { Vertical and } \\
\text { horizontal }\end{array}$ \\
\hline Poland & Horizontal & Vertical & Domestic fields & Vertical \\
\hline France & Horizontal & Horizontal & Vertical & $\begin{array}{l}\text { Vertical and } \\
\text { horizontal }\end{array}$ \\
\hline Sweden & Vertical & - & $\begin{array}{l}\text { Vertical and } \\
\text { horizontal }\end{array}$ & - \\
\hline Norway & - & Vertical & - & Horizontal \\
\hline
\end{tabular}

* Light grey: some importance, white: almost no importance 
a specific policy recipe dominates within the European environment, the stronger the effect it may have on policy development at the domestic level. Vertical Europeanization refers to top-down EU steering: the greater the structural power controlled by the EU, the greater will be the impact on domestic policy development.

Chapter 4 described a gradual increased strength in vertical Europeanization, peaking after 2010 and with two peaks in horizontal Europeanization: a fixed feed-in trend from 2000 to 2009, and a feed-in premium trend combined with competitive auctions emerging after 2010. After 2010, the horizontal and vertical Europeanization processes created an EU governing situation, so we should expect the European environment to have become especially salient for domestic support-mix developments after 2010. In fact, however, the pattern of European environment influence over time (see Table 11.1) does not fit this description. This calls for a more detailed assessment of the role of the European environment in differing phases, taking account of developments in all six case-countries.

The EU had little formal authority in the period leading up to 2000, and vertical Europeanization was weak. The European Commission (the Commission) promoted a pan-European electricity certificate scheme, but the member states approached the issue in different ways, so horizontal Europeanization was also weak. From 1990 and onwards, the Commission started to regard renewables support as an EU state-aid issue, but it readily adopted all notified support schemes and did not perform actual steering. That was a 1000 flowers situation, where we would expect countries to test out a range of new solutions, without being deeply affected by developments elsewhere in Europe. However, we find that the European environment influenced three out of our six case-study countries in this period.

Poland adopted technology-specific feed-in (inspired by Germany), and France adopted rather technology-neutral tendering (inspired by the UK). Both developments seem to have come about because domestic actors looked to other countries to find new policy ideas - not because of strong pressures from the European environment. In addition, Sweden was influenced by the Commission's campaign for a technology-neutral pan-European certificate scheme. The vertical steering signals were weak, but domestic actors were receptive to the Commission's arguments: hence, that Sweden adopted a certificate scheme was largely a result of drawing lessons from abroad. Interestingly, 30 years later, the domestic support mixes in Sweden and France bear the hallmarks of the initial European impulse from this period. In Poland, by contrast, this initial European environment impulse faded quickly.

The 2000-2004 period was dominated by horizontal harmonization. The Commission argued that the EU member states had to adopt more technology-neutral schemes in order to act in accordance with the state-aid guidelines, but the CJEU PreussenElektra ruling ensured that technology-specific feed-in was recognized as legal under EU law. Hence, in this period, the Commission did not gain any forceful authority with a basis in state-aid rules. The EU adopted its first Renewables Directive - but, as the Commission's proposal for a binding, technologyneutral support-scheme was rejected, vertical Europeanization remained limited. 


\section{2}

Moreover, feed-in diffused rapidly. Hence, the period was characterized by horizontal harmonization, in turn underpinning the development of feed-in in France. Although feed-in (and not certificate schemes) gained in popularity during this period, Norwegian actors were receptive to the certificate idea from the Commission and the European electricity industry. Despite the absence of strong vertical Europeanization pressure for certificates, the idea gained acceptance in Norway, although it took years before it came into fruition.

The Commission had somewhat more authority over Poland because of its accession status, so Poland experienced stronger vertical Europeanization pressures than the other countries in the 2000-2004 period. This partly explains why Poland prepared for a shift to a certificate scheme in this period (adopted in 2005), overruling the initial European environment effect on Polish developments (which had led Poland to adopt a feed-in scheme). However, EU steering cannot explain why the Polish scheme promoted co-firing of biomass in co-firing coal-power plants, and not wind and solar.

As Germany was the source of the European trend in this period, it was hardly 'a taker' of European environment impulses. Further, neither the UK nor Sweden was much affected by European developments. Given the lack of strong vertical Europeanization, it is not surprising that the European environment affected different countries in different ways. Due to domestic differences, the European environment contributed to introducing technology-neutrality in Poland and Norway, but technology-specificity in France (to which we return later). Moreover, the overall salience of the European environment proved to be higher than expected in this period.

In the 2005-2009 period, the authority of the EU increased, due to the introduction of binding renewables targets. Hence, a certain indirect $E U$ governing was added to the horizontal harmonization character of the European environment. These two modes of Europeanization existed in parallel because of the 2007 European Council decision to adopt binding, domestic renewables targets for 2020, and because feed-in became increasingly dominant. The Commission could not steer how member states designed their support mixes, but it could pressure them to adopt schemes that could fulfil the targets. Germany, already having high renewables ambitions and being the feed-in leader, was not much affected by the European environment, but we detect significant effects in other countries.

The UK and Sweden were influenced by the greater focus on small-scale production all over Europe. Sweden, however, adopted a more technology-neutral instrument than the other countries. Despite the historically strong dominance of market logic in the UK, and the prior technology-neutrality of its large-scale scheme, the country adopted a feed-in for small renewables plants, influenced by the German feed-in. The UK also introduced greater technology-specificity in its large-scale support schemes. The shift towards technology-specificity in the UK came about partly because of Prime Minister Tony Blair's bold support for adoption of binding domestic EU renewables targets. When the EU later gave the UK a high target (compared to its low initial share), this eventually strengthened the domestic actors that for a long time had argued that the UK needed greater 
technology-specificity. This added to the effect of the strong vertical Europeanization (due to the dominance of feed-in) and the high EU-wide focus on fostering small-scale renewables. Also in France, the EU-level actions of President Nicolas Sarkozy boomeranged, strengthening the domestic actors that wanted greater technology-specificity.

The EU-wide emphasis on small-scale renewables and the new renewables targets also influenced Sweden. However, in line with its traditions, Sweden adopted technology-neutral investment support for small-scale renewables. Poland was rather unaffected by developments in the European environment in this period. Likewise, Norway remained rather isolated from the new European environment, although the old certificate impulse lingered. For instance, it seems that since Norwegian politicians had not been involved in negotiating the Renewables Directive (as an EEA member, Norway is required to adopt certain EU laws but does not have formal access to the EU decision-making process), neither the adoption of new targets nor the diffusion of feed-in schemes in Europe attracted much attention in Norway. Overall, we find that most of the EU steering was directed at increasing the share of renewables, whereas horizontal Europeanization had a more direct impact on the support-scheme mixes. The authority of the EU had increased, but still the importance of the European environment was rather similar to prior periods.

After 2010, we see a clear upward shift in the salience of the European environment. It plays a significant role for all countries in this period, except Sweden, but it does not determine the course of developments in any of the countries. The EU steering of renewables support schemes was becoming radically stronger, through new state-aid guidelines that favoured auctioning combined with feed-in premiums and promoted technology-neutrality. Electricity certificates were accepted by the EU but were not promoted by the new guidelines. In parallel with the deliberations over the new guidelines, the UK, France and Germany prepared a shift towards feed-in premiums combined with auctioning - in effect, a new trend. With vertical and horizontal Europeanization increasing in tandem, the European environment shifted to EU governing. Strong domestic forces underpinned developments in the UK, France and Germany, but the adoption of the new EU state-aid guidelines in 2014 stands out as decisive for domestic-level developments, especially in France and Germany. Interestingly, all three counties continued to have schemes that were more technology-specific than prescribed by the Commission.

The European environment did not have an equally strong impact on renewablessupport mixes in Poland, Norway or Sweden. Poland did change its large-scale scheme, but not because the new guidelines required this. After all, Poland already had a certificate scheme largely in line with the guidelines. Rather, it seems as if the shift in support scheme was primarily a strategic move, aimed at worsening the conditions for the development of large-scale renewable projects. Poland also introduced new schemes for small-scale renewables, but the process was opaque, and it is not easy to ascribe these developments to EU steering. Norway was influenced by the greater European-wide focus on small-scale, introducing a modest investment support for small-scale renewables. However, that scheme was far 
more limited and more technology-neutral than small-scale support schemes in the other countries. Moreover, Norway's decision to not prolong the certificate scheme was not influenced by the European environment.

Support schemes in Sweden were not influenced by the shift in EU steering at all - hardly surprising, as Sweden already had a large-scale scheme largely in line with the new rules, and it had adopted a small-scale renewables support scheme a few years earlier. Interestingly, Sweden retained its electricity certificate scheme, although such arrangements had fallen out of favour almost everywhere else.

All six countries would have ended up with different renewables support mixes if it had not been for enablers and constraints within the larger European environment. In fact, the European environment contributed to spur differentiation between the technology-specific and technology-neutral countries. As we will see, the growing salience of the European environment after 2010 occurred in parallel with domestic factors that also gained salience, which means that there is an interrelationship between domestic and European factors.

\section{Organizational fields: crucial but not totally dominant}

The case-study comparisons presented in Table 11.2 show that even though the organizational fields of stationary energy tend to be segmented most of the time in most countries, there is interesting variance in the policy salience of the segmented fields. Initially, we expected that the organizational fields would dominate the development of domestic renewable energy policies more when the organizational field is characterized by centralized structural resources and one dominant institutional logic (segmentation). While we find that segmentation tends to make organizational fields more important for policy development, not all segmented fields are equally important. Hence, segmented organizational fields are crucial but not totally dominant - and are thus generally less important than we initially assumed.

A brief glance at Table 11.2 shows our expectations are largely supported, although there is still greater variance in the importance of segmented

Table 11.2 Comparing the role of the organizational field across time and cases*

\begin{tabular}{lllll}
\hline $\begin{array}{c}\text { Period } \\
\text { Country }\end{array}$ & Before 2000 & 2000-2004 & 2005-2009 & 2010-2016 \\
\hline Germany & Pluralist & Turf battle & Turf battle & Segmentation \\
UK & Segmentation & Segmentation & Segmentation & Segmentation \\
Poland & Segmentation & Segmentation & Segmentation & Segmentation \\
France & Segmentation & Segmentation & Segmentation & Segmentation \\
Sweden & Segmentation & Segmentation & Segmentation & Segmentation \\
Norway & Segmentation & Turf battle & Turf battle & Segmentation \\
\hline
\end{tabular}

* Dark grey: high importance, light grey: some importance, white: almost no importance. 
organizational fields than we had expected. In all countries, the organizational fields played a considerable role in policy development in at least two periods. Their relative importance increased after 2010 - in some cases this happened as the degree of segmentation increased, but in other countries the importance of the organizational field increased even though the degree of segmentation remained roughly the same. At this stage, renewables had become more mainstream, and all countries had achieved some new renewables production. In Germany and Norway the variation in the role of the organizational field is generally in line with variation in segmentation, but this pattern is less clear-cut for the other countries. In Poland and Sweden, we find periods where the organizational field had less salience for policy developments, even though the degree of segmentation was high.

Let us then first assess the countries where the organizational field has dominated support-mix developments more when it has been segmented than when characterized by turf battles or pluralist patterns: Germany and Norway.

In Germany, the organizational field became more important after 2010, when structural resources had become more concentrated and institutional conflicts were lower. In the first period, large utilities benefitted from exclusive supply contracts with the municipalities and established regional monopolies. Although such monopolies did not represent pluralism regionally, the field had a more pluralist nature at the national level, with room for the political field to dominate the initial development of Germany's support scheme. German reunification in 1990 contributed to this pluralist nature by causing de-institutionalization; the merger of two different domestic fields of stationary energy production created a host of challenges for all actors involved. Dominant public and private actors had more pressing issues to attend to than concocting a new renewables support scheme.

After 2000, the initial feed-in scheme had contributed to the creation of a range of new renewable-energy actors, embedded in a technology development logic. In parallel, the traditional utilities became increasingly dominated by market logic. This spurred recurrent and tense institutional conflicts over renewables support. That the Ministry of Environment was given formal responsibility for renewables support served to strengthen the renewables actors and the technology logic. From 2000 to 2009, there were arguably two turfs, embedded in different logics and each with rather significant authority and ability to process information, constantly challenging each other. Due to deep-seated conflicts at the organizational field level, other fields - both the domestic political field, and EU actors were repeatedly mobilized to help in solving the fierce conflicts over renewables support schemes. The ongoing turf battles in the organizational field enabled the political majority in Germany to determine quite independently which organizational field actors would gain the most influence. They often favoured the renewables actors over the incumbents and this resulted in a series of incremental changes to the initial feed-in.

After 2010, the boundaries between renewables actors and traditional utilities became less clear-cut as utilities invested more in renewables, and some renewables technologies became so profitable that they needed less technology-specific 
support. Moreover, more actors seemed to combine elements from the two different institutional logics, aiming to come up with new business models and support-scheme ideas that could ensure that the rising share of renewables had a less distorting impact on the overall functioning of the German energy system. In addition, the traditional electricity utilities gained leverage - because they were in a dire economic situation, but also because responsibility for renewables support was shifted from the Ministry of Environment and into the Ministry of Economic Affairs. The latter ministry also had with responsibility for other energy policy.

As the degree of segmentation increased, field-level deliberations, negotiations and developments became crucial to the ensuing shifts in the German support scheme. EU developments and political field changes also affected developments. The situation was highly complex, but the organizational field came to play a pivotal role in the end - and, in line with our expectations, a more important role after it had become segmented.

In Norway, the field was initially segmented, and because the dominant fieldlevel actors had little interest in developing new renewables support, no stable scheme emerged. However, by the end of the 1990s, the major utilities were becoming interested in windpower. Energy liberalization had made the commercial sector align to market logics while the Ministry of Petroleum and Energy was embedded in a distinctly Norwegian logic of minimizing societal costs. This logic contrasted with the market logic in many respects. Auctioning, combined with a technology-neutral feed-in premium mechanism proposed by the Ministry of Petroleum and Energy and endorsed politically in 2000, was opposed by the utilities. The ensuing turf battles between the commercial actors and the ministry obstructed the implementation of the new scheme and new renewables projects.

Eventually the utilities, with support from environmental groups, gathered political support for a shift to a technology-neutral certificate scheme, but that shift was caused primarily by political dynamics. It took many years before Norway joined the Swedish scheme - and when this finally happened, the utilities had realized that the increased electricity production resulting from the scheme would reduce electricity prices and thereby the profitability of their large hydro portfolios. By now, public and private organizations had become more united, both voicing concerns about the low profits of the electricity utilities. The increased segmentation of the field continued to explain why Norway eventually decided to withdraw from the certificate scheme, even before the scheme had spurred many projects in Norway. Introduction of a marginal technology-neutral investment support for small-scale renewable energy projects also reflects the market logic of the segmented organizational field. Thus, in many ways, the Norwegian supportscheme mix around 2016 can be said to be a product of a segmented field.

Neither in Germany nor in Norway were the shifts and changes in the support mix after 2010 exclusively the result of field-internal developments, but the field clearly played a more important role for policy development when it was segmented. In both countries, the dominant corporate actors - the electricity utilities quite significantly changed their preferences over time, with major consequences for the development of the renewables support schemes. In Norway, change in the 
perceptions of the dominant utilities was the prime driver of changes in the largescale support scheme in 2010. The picture is more complex in Germany, where field-level developments were more intertwined with political field change and shifts at the EU level. As a result of a whole host of developments, the large Germany utilities shifted from favouring technology-neutrality to accepting a fairly technology-specific renewables mix, whereas the Norwegian utilities changed from promoting a technology-specific mix to wanting to do away with all support. In both countries, the utilities changed their positions, but their preferences did not become more similar over time.

We now turn to the four case-study countries - the UK, Poland, France and Sweden - where the roles played by the organizational fields are less well aligned to our initial assumption, asking: Is the variance in the importance of the organizational field explained by field-internal changes too subtle to be captured by our initial two-by-two model (see Chapter 3)? Or is it caused by developments in the political field or the European environment?

The British organizational field remained segmented for a long time. The new market logic that resulted from the liberalization process swiftly gained a foothold in the 1990s, and this influenced the design of the first British support scheme, although few organizational field actors were particularly involved in this initial phase. Then, from 2000 and onwards, segmentation increased further. There were six dominant utilities; they had a strong relationship with the regulators, and they were all embedded in a similar market logic. Since the initial technology-neutral scheme failed to result in significant new production, few actors had a vested interest in protecting the initial scheme. That circumstance made possible a swift shift to another technology-neutral support-scheme design. Eventually, however, around 2010, there came a shift towards technology-development logics among the traditional utilities, due partly to their interest in developing nuclear. At this stage, some renewables actors were sceptical to greater technology-specificity, because they feared that this could favour nuclear and not renewables. However, they did not attract much attraction in the policy debate - and the field remained segmented, although the number of renewables actors had increased.

Institutional change at field level resulted in the special British auctioning and feed-in premium system - the Contracts for Difference. Later, changes in the political field led to shifts in how this scheme was operated, with fewer auctioning rounds than expected and thus less support. Still, the design of the new scheme was a result of a shift in institutional logic within the organizational field. The British feed-in support for small-scale renewable energy projects, however, was, as we discuss later, primarily the result of developments in the political field. In most instances, shifts in the British support mix were underpinned by changes in the dominant institutional logic of the organizational field. The British case shows how the institutional logic in a field may change without spurring conflicts that reduce the degree of segmentation.

The upshot is that changes in the British scheme in the period 2000-2004 and after 2010 were mainly the result of internal changes in the organizational field, while the field played a less clear role for developments before 2000. The 
adoption of small-scale support in the period 2005-2010 is better explained by developments in British politics, whereas the organizational field was of greater importance for the development of the support scheme for large-scale, low-carbon projects.

Poland has always had a strongly segmented field; still, the organizational field has not completely dominated the development of support schemes. The field has a special kind of technology-development logic, focused on the continuation of coal production, rather than renewables development. This logic seems to have remained largely unchanged over time. Initially, ministerial actors had the upper hand, but the coal utilities gradually became structurally dominant. The instability in renewables support contrasts with the stability found at the organizational field level. The chief explanation for this mismatch may be that the powerful utilities seem to have been less concerned about the type of support, and more about its (in)effectiveness.

The initial technology-specific feed-in scheme was introduced as a token adjustment to Western values after the fall of Communism. It is not surprising that policy development in a period of upheaval should differ from our expectations, which were formulated for more mundane policy-development processes. Later on, Poland largely introduced wide-ranging support-scheme changes in response to EU steering and European trends, but the segmented organizational field undermined the emergence of Polish renewables actors. Hence, renewable production never really became institutionalized within the Polish energy sector. There was considerable political commotion after 2010 , but eventually there came a shift towards giving large-scale renewable energy projects technology-specific support and a new, marginal support for small-scale producers (prosumers). The segmentation of the organizational field thus had a major impact, bringing instability and hindering institutionalization of renewables support, even though it appears not to have had much influence on the design of the support scheme. Hence, we conclude that variance in the importance of the organizational field in Poland is not related to changes in the degree of organizational field segmentation.

Initially, the French field was segmented, with one totally dominant utility, Électricité de France. (EDF). Historically, the EDF has been embedded in a centralized nuclear-technology development logic, although it welcomed some market logic features during the 1990s. To a certain extent, the French adoption of a tendering measure in the mid-1990s, inspired by the UK, was in line with the increased market focus in the EDF at the time. But this may also be understood as primarily a symbolic gesture, enabling the EDF to appear positive to market thinking and renewables, while at the same time assuming that the new measure would not actually lead to much new production. In the period 2000-2004, France first adopted feed-in, in contrast to EDF recommendations, but later the EDF succeeded in reducing the strength of the feed-in. Eventually, however, the old centralized nuclear-technology development logic of all the dominant French actors was challenged by an alternative decentralized technology-development logic, and the EDF was not able to stand united against change. 
By 2010, the generous French feed-in scheme had spurred a host of new renewables actors, and the governmental organizations had gained experience in how various actors responded to differing support schemes. Moreover, the Ministry of Ecology had taken over responsibility for renewable energy. Even though this rendered the field slightly less segmented than before, the EDF continued to have a very strong position. In essence, the incremental changes in the French scheme came about by trial and error, deliberations and a modest strengthening of the decentralized technology development logic within the organizational field. The French field was less segmented than before, but segmented nonetheless. By now it included actors that were willing and able to focus on energy sources other than nuclear. Although the French case largely confirms our initial expectations, it is puzzling that the French organizational field became more important after 2010. This is a result of French developments moving in tandem with developments within the European environment.

In Sweden, civil servants introduced the technology-neutral electricity certificate idea (from the Commission). Eventually corporate actors as well as politicians endorsed it, as it was in line with the recent liberalization of the Swedish energy market. From 2000 and onwards, all major field-level actors in Sweden seem to have accepted and underpinned continuation of the electricity certificate scheme. The small-scale renewables support that was adopted after 2005 was promoted mainly by marginal actors inspired by European developments. They succeeded due to strong political support, and despite the crucial role that Vattenfall and a few other utilities played in the organizational field.

After 2010, the organizational field in Sweden largely turned against the electricity certificate scheme (although not all actors agreed) - but, surprisingly, this had no impact on decision-making. Even though the Swedish and Norwegian situations were quite similar after 2010, the organizational field was far less influential in Sweden than in Norway. Despite the field being rather segmented, and with both public and private actors questioning the existing scheme, Swedish politicians agreed to prolong it to 2030. True, the Swedish field was somewhat less segmented than previously, not least because of a host of new renewables actors. Still, it is surprising that the field could be so completely overruled.

Hence, Swedish developments after 2010 run counter to our initial expectations. At this stage, the Energy Agency in Sweden had grown quite powerful and some new renewables actors had emerged, and this to some extent counteracted the influence of the dominant utility Vattenfall. The main reason that the organizational field in Sweden was overruled after 2010 seems to be the special and intense situation of political salience, although a slight reduction in segmentation in the organizational field also contributed.

Against this backdrop, we conclude that differences in institutional logics between the organizational fields in Germany, Poland, France and the UK on the one hand, and Sweden and Norway on the other, contribute to explain the emergence of the difference between technology-specific countries and technologyneutral ones, although other fields also have played a role here. Moreover, we see that segmentation tends to ensure that the organizational field becomes the crucial 
locus for changes and stabilities in renewables support mixes - but this field is never alone in determining policy developments. Most importantly, political field dynamics may overrule factors internal to the organizational field, even when it is segmented.

\section{Political fields: surprisingly important}

We find significant variance across countries, and over time, in how domestic political fields play into support-mix developments. To a certain extent, this is a result of changes over time in the degree of political salience and distribution of structural resources in the political fields. Initially, we expected the political field to dominate the development of domestic renewable-energy policies most in a situation characterized by distributed structural resources and high-salience (legislature governing). Indeed, we see that the political field is more important when it is in this legislature governing mode. However, the political field is also important under other conditions: on the whole, it emerges as more important than we had assumed.

Table 11.3 summarizes the roles played by the political fields in the development of renewables support schemes in the six countries. The table indicates that up to 2005, the political field had low salience in most countries, but this changed significantly after 2005 . The political field played a more central role between 2005 and 2009 than in any other period, but it was also surprisingly important after 2010. This greater political salience had considerable consequences for small-scale support: in several countries, politicians initiated the adoption of special schemes for small-scale renewables in this period. In fact, Norway appears

Table 11.3 Comparing the role of the political field across time and cases*

\begin{tabular}{|c|c|c|c|c|}
\hline $\begin{array}{l}\text { Period } \\
\text { Country }\end{array}$ & Before 2000 & $2000-2004$ & $2005-2009$ & $2010-2016$ \\
\hline Germany & Politicizing & $\begin{array}{l}\text { Legislature } \\
\text { governing }\end{array}$ & $\begin{array}{l}\text { Legislature } \\
\text { governing }\end{array}$ & $\begin{array}{l}\text { Legislature } \\
\text { governing }\end{array}$ \\
\hline UK & $\begin{array}{l}\text { Ministerial } \\
\text { governing }\end{array}$ & $\begin{array}{l}\text { Ministerial } \\
\text { governing }\end{array}$ & Politicizing & $\begin{array}{l}\text { Ministerial } \\
\text { governing }\end{array}$ \\
\hline Poland & - & $\begin{array}{l}\text { Ministerial } \\
\text { governing }\end{array}$ & $\begin{array}{l}\text { Ministerial } \\
\text { governing }\end{array}$ & Politicizing \\
\hline France & $\begin{array}{l}\text { Ministerial } \\
\text { governing }\end{array}$ & Politicizing & Politicizing & $\begin{array}{l}\text { Ministerial } \\
\text { governing }\end{array}$ \\
\hline Sweden & $\begin{array}{l}\text { Ministerial } \\
\text { governing }\end{array}$ & $\begin{array}{l}\text { Ministerial } \\
\text { governing }\end{array}$ & $\begin{array}{l}\text { Legislature } \\
\text { governing }\end{array}$ & $\begin{array}{l}\text { Legislature } \\
\text { governing }\end{array}$ \\
\hline Norway & $\begin{array}{l}\text { Ministerial } \\
\text { governing }\end{array}$ & $\begin{array}{l}\text { Ministerial } \\
\text { governing }\end{array}$ & Politicizing & $\begin{array}{l}\text { Ministerial } \\
\text { governing }\end{array}$ \\
\hline
\end{tabular}

\footnotetext{
* Dark grey: high importance, light grey: some importance, white: almost no importance.
} 
to be the only country where the adoption and design of small-scale support were not heavily influenced by political dynamics - but Norway also has a far less extensive small-scale scheme than the others.

Legislature governing is relatively rare, as we detect only five such periods: three in Germany (2000-2004, 2005-2009, 2010-2016) and two in Sweden (2005-2009, 2010-2016). In all these periods, the political field played a central role in the development of renewables schemes, and in three, the political field was dominant.

Ministerial governing is the most dominant political field mode, detected 12 times; and in most of these cases, the political field had only minor impact on the development of the support-scheme mix. Given our initial expectations, it is still surprising to find that, in 3 of the 12 instances, the political field had substantial importance for the development of support schemes. We identify six periods characterized by politicizing, and in all of them the political field played a significant role in how the renewables-scheme mixes developed. Thus, the political field emerges as more important in such situations then we had expected. Let us now explore in greater detail why the political fields have played differing roles in different countries.

Germany stands out as a country where the political field has been the main driver of the development of the support mix, although its relative salience decreased after 2010. First, the political field was more important for initial adoption in Germany than elsewhere. At this stage, politicians contributed to making the issue salient, but some time passed before the traditionally strong organizational field actors - the electricity utilities in particular - started to protest against the feed-in scheme. The push-back from these actors continued to ensure that the issue remained politically salient for a very long time. From 2000 to 2010, political field dynamics played the dominant role in enduring the continuation of the German scheme; even though the scheme was adjusted several times, these were incremental changes, in line with the path embarked on in the early 1990s. Germany has a strong parliament, and this created structural conditions that allowed legislature governing, while the decision to transfer renewables responsibility to the Environmental Ministry added to this.

The long period of legislature governing in Germany helps to explain why, after 2010 , Germany exposed renewables investments more to electricity price developments. That the politicians for a long period refrained from giving the utilities what they wanted created a boomerang effect. Because the feed-in scheme together with other factors eventually contributed to weakening the economic position of the large utilities, and they were 'too large to fail', many politicians eventually changed their minds and allowed these actors greater influence on the development of support schemes. Moreover, the critical situation after 2010 forced politicians, corporations and public officials to engage in deeper deliberations with one another. Since the issue had high salience and structural resources were distributed between many political actors, the political field gained the upper hand: legislature governing spurred a succession of political conflicts and compromises. In the first periods, the German case fits with our expectations; but after 
2010 , the increased strength of the organizational field and the European environment led to a complex process of policy development that involved many actors from multiple fields.

Developments in the $U K$ are not equally in line with our initial expectations. For many decades, ministerial governing remained dominant. However, in 20052009 , politicization became evident, when small-scale renewables became subject to political competition; this eventually led to the adoption of a feed-in scheme for small-scale renewables. In the same period, politicization also occurred as a result of Prime Minister Tony Blair's engagement in EU deliberations, endorsing a high renewables target had implications for the UK's support schemes, towards greater technology-specificity (more high-cost renewables were deemed necessary to reach the target). After 2010, the large-scale scheme became radically more technology-specific. This obtained political endorsement, but the main explanation for the shift lies in the organizational, not the political, field. The 2015 elections had a major influence on how the new technology-specific scheme would be operated, with very few auctions taking place. This shows that in the UK system, the political field can be very powerful even when an issue is dominated by ministerial governing.

The special political system in the UK appears to make ministerial governing both more prevalent and potentially more powerful than in other countries. The UK has a two-party system, where the party with a majority in Parliament tends to control the government. This makes the dynamics of the political field different from what we had expected; as the structural resources are never really distributed, this dimension is less analytically useful here. Control of the executive branch matters much more than in the five other countries, and this has had profound effects on the dynamics in the political field. In any event, in the UK the initial technology-neutrality and the eventual shift to technology-specificity came about primarily because of developments in the organizational field - the exception being the politically induced small-scale feed-in.

Despite the peculiarities of the Polish political system, the political field perspective captures central aspects of how politics have played into support-scheme developments. The exception is the initial adoption of a support scheme, which took place in a period where a new political system was in the making and was thus hard to capture analytically. From 2000 and until 2010, however, the Polish political field was in ministerial governing mode; and, in line with our expectations, the political field had very little impact on policy development in this period. After 2010, the issue became politicized and the Polish Parliament influenced the support scheme for small-scale, but soon a new parliamentary majority introduced less-favourable legislation. While we note considerable unpredictability and shifts in the decision-making process, making it challenging to pinpoint what importance it actually had in this period, the political field had at least some impact on support-scheme developments, particularly for small-scale projects.

In France, the initial, rather technology-neutral scheme was adopted under ministerial governing conditions, and in line with our expectations, the political field had hardly any influence. After 2000, renewables became politicized, and 
this had major importance for the adoption of the feed-in scheme. In 2005-2009, the political field influenced the revision of the scheme, but renewables support gained salience primarily because of the French President's commitments to higher renewables targets at the EU level. Moreover, significant adjustments in the support scheme after 2010, towards more auctioning, were made without the political field apparently playing much of a role - as expected under ministerial governing.

In Sweden, the political field was not very important for the initial adoption of a certificate scheme. As expected, the political field started to influence the development of the scheme only after the issue became salient in the 2005-2009 period, but it was not until after 2010 that the political field became the key driver, ensuring protection of the technology-neutrality of the scheme. The latter point is truly remarkable, in view of the resistance from the organizational field after 2010. Indeed, this is the only case where we find a rather segmented organizational field being overruled by developments in the political field. This is an essential element in explaining the technology-neutrality of the Swedish scheme after 2016.

In Norway, the political field played a minor role for the development of support schemes in the years leading up to 2005. After this, conflicts at the level of the organizational field made the issue increasingly salient, until finally the political majority abolished the existing scheme and shifted towards technology-neutral electricity certificates. After 2010, however, the political majority merely rubberstamped proposals developed by dominant actors within the organizational field. By then, Norwegian utilities had had a change of heart and readily got political endorsement for not including more Norwegian projects in the certificate schemes after 2010. In short, political field dynamics contributed to Norway's opting for technology-neutrality, but the key drivers for later changes lay elsewhere.

Overall, we see that the political field has been crucial for the development of renewables-support mixes. Indeed, under certain rare conditions, it can remain the main driver of policy stability as well as change for extensive periods.

\section{Multi-field dynamics}

The assessments presented thus far in this chapter show clearly that the renewablessupport mixes in our six case-study countries in the late 2010s all resulted from dynamic developments within multiple fields, and their interaction over time. Both domestic fields (the political as well as the organizational) and the European environment have influenced policy developments in all six countries. Indeed, we cannot gain a good understanding of any of the six domestic policy processes without taking this multi-field nature into account.

We now turn to how and to what extent the varying fields have influenced developments in other fields. More specifically, we show that

1 segmentation within the organizational field tends to produce ministerial governing within the organizational field, and this enhances the autonomy of the organizational field over time; 
2 while the social architecture of the organizational field tends to remain fairly (but not fully) inert, the political fields are more malleable, and this has profound effects on how policy processes unfold over time;

3 domestic policy developments in some countries are far more interdependent and intertwined with EU-level developments than other countries; and

4 the multi-field process is not a zero-sum game: several fields may be important simultaneously, and the more fields that have an impact, the more complex and murky the policy process is.

\section{Segmentation spurring ministerial governing}

Let us first assess the relationship between the political and domestic fields. We have analysed how the organizational and political fields match over 24 periods (four periods in six countries), and the organizational field is segmented in 19 of these. In 12 sub-cases, the political field is in the ministerial governing mode. Indeed, the most frequent combination is segmentation in the organizational field and ministerial governing in the political field: it occurs twice in four countries (the UK, Poland, Sweden and Norway) and three times in France - but never in Germany. In these situations, the organizational field drives support-scheme developments, while the political field primarily performs rubber-stamping. But why do ministerial governing and segmentation go together so well? Systematic examination of the chronological relationship between the two modes may offer a better understanding of this causal relationship.

Let us first compare the cases where segmentation remained unchanged over several periods, but where the mode of the political field changed. In the UK, Poland, France and Sweden, 'segmentation-ministerial governing' situations changed to segmentation combined with either legislature governing or politicizing. Incremental changes within the political field spurred these shifts in the mode of the political field, sometimes combined with European environment developments. Ministerial governing was combined with another organizational field mode than segmentation in only one instance: Norway in the 2000-2004 period, when ministerial governing was combined with turf battle. This was a temporary situation, as the turf battle within the organizational field eventually created politicizing within the political field. This shows that conflicts within the organizational field can spur changes in the mode of the political field - but in our sample, that is more the exception than the rule.

Germany is the only case where the organizational field was not segmented most of the time. Here, the conflicts between the two turfs at the level of the organizational field ensured that renewables support had high political salience. Comparison of Norway and Germany illustrates how the political field may respond to organizational field turf battles. In the Norwegian case, the political field was mobilized to solve conflicts at the level of the organizational field. It did take several years before the issue became salient, but eventually the politicians responded by adopting a new support scheme. However, this decision did not spur the creation of new firms or business models that could undermine the 
segmented state of the organizational field. Rather, together with other factors, it led to greater segmentation, and the issue was again dealt with as ministerial governing within the political field. Thus, later changes in the support mix in Norway after 2010 were solved through negotiations between field-level actors, merely rubber-stamped by the political majority.

In Germany, turf battles at the organizational field level had much longerlasting effects on the mode of the political field, but the impact also runs in the other direction: a series of political decisions challenged the dominant organizational field actors, the utilities. The initial renewables support strengthened the new renewables actors, and this in itself hindered segmentation of the field, in turn contributing to the continued high political saliency of the issue. Because the political majority had committed to technology-specificity, this approach was sustained, which again strengthened the position of the renewables actors. Hence, legislature governing decision-making hindered segmentation in the organizational field, which again ensured that the dominance of the legislature governing mode was remarkably long-lasting. The clashing dynamisms between the two domestic fields forced actors within both of them to devote considerable attention and creativity to the issue for a long time, eventually leading to creative processes and merging of two institutional logics previously regarded as opposites. When this happened after 2010, a segmentation process set in at the organizational field level. However, it took almost two decades before such collaborative and creative processes emerged.

The 'segmentation spurring ministerial governing' tendency means that we can expect major political decisions relating to segmented organizational fields to be resolved through negotiations between organizational field-level actors, and not through open political deliberations. Note that this does not necessarily imply that the commercial organizations have the upper hand; public governments may also be influential in such situations. Moreover, this is only a tendency, not a rule. It may require considerable effort, but politicizing issues under such conditions is not impossible. Indeed, we find many examples of political dynamics gaining salience also when the issue pertains to a segmented organizational field.

\section{The inertia of organizational fields and the malleability of political fields}

We detect rather few shifts in the degree of segmentation in the domestic organizational fields over time. In most countries there have been only slight shifts from rather segmented to fully segmented, or the reverse. The German and Norwegian organizational fields are different. While the Norwegian field merely shifted from segmented to turf battle and back again, the German field changed incrementally and substantially over time, from pluralist to eventually becoming segmented. German reunification resulted in less unity within the organizational field of electricity than seen in most other European countries. Eventually, the German renewables support scheme contributed to the creation of a host of new actors that in turn led to conflicts and obstructed segmentation. In Norway, periods with less 
segmentation were primarily the result of conflict between governmental organizations and the utilities

In all the other case-study countries - the UK, Poland, France and Sweden the organizational fields remained more or less segmented throughout the whole period. True, conflicts over renewables policy may have created slightly less unity within these organizational fields, but not enough to change the degree of segmentation significantly. However, it should be borne in mind that renewables support schemes, or conflict over these schemes, are merely one among a whole range of factors that may undercut segmentation, or strengthen it. With the exception of Germany, renewables policies seldom influence the degree of segmentation within organizational fields.

Political fields are far more malleable to change. It is particularly the high/low salience dimension in the political field that changes, whereas the distribution of structural resources is less malleable. We have detected three main reasons for shifts towards greater salience. First, changes in salience may result from processes internal to the political field. This may be due to changes in the political majority, to the emergence of new political alliances or to shifts in the size of various political parties in the parliaments after an election. For instance, politicians from differing political parties created a surprising new alliance for feed-in in Germany during the 1990s, but later election results in Germany also created alliances that underpinned the salience of the issue. In other instances, marginal political actors almost single-handedly succeeded making renewables support more salient. The clearest illustration of this in our sample is the Green Party in France, which managed to politicize renewables support in the 2000-2004 period, in turn leading the other political parties to develop a more active approach to the issue as well. Part of the explanation to this shift was that the Green Party was included in the governmental coalition for the first time, giving the Greens far more authority to promote the issue than otherwise.

Second, high salience can result from conflicts at the level of the organizational field. This happened in Germany in 2010-2016, and in Norway in 2005-2010. In both cases, the political parties shifted their positions in response to developments in the organizational field; in the end, key actors from both fields engaged in negotiations and developed solutions that could gain acceptance within both fields. In Norway, it took many years before politicians responded to the organizational field conflict, and the politicization did not last long. By contrast, the issue remained politicized for a long time in Germany, and two decades of tumultuous conflicts between the political and the organizational field reinforced the enduring political salience.

Third, we detected two instances of issues becoming highly salient because political leaders made bold domestic commitments at the EU level, seeking to influence EU-level developments. In the 2005-2009 period, both French President Sarkozy and British Prime Minister Blair committed their countries to adopting the 2020 renewables targets that were binding on the EU level - and in both instances, this later bolstered the arguments of domestic actors calling for more elaborate domestic support schemes. Hence, the interrelationship with EU-level 
developments helped to enhance the clout of the domestic political leaders, and it spurred politicization at the domestic level.

To a certain extent, the malleability of the political fields can compensate for the de-politicizing effect of high degrees of segmentation at the level of the organizational field. Even when an issue relates to a segmented organizational field, politicization is possible - if politicians follow the issue for some time and engage sufficiently to gain a good understanding of it, they may in the end make decisions counter to the arguments of powerful actors in the organizational field. It is especially interesting to note that national political leaders can use their European positions to enhance their clout in relation to strong domestic organizational fields.

\section{Varying interdependencies between domestic fields and the European environment}

The interdependence between the domestic and the European environment varies across countries, as well as over time. Germany is in a special category, as it has played a crucial role for developments in both vertical and horizontal Europeanization, and it has also been highly dependent on EU decision-making for its own domestic policies. Germany has been the major determinant of EU policy development, serving as the main source of inspiration for other European countries but after 2010 it also significantly changed its support mix (partly) as a result of EU steering. Poland, France, Sweden and Norway have all been influenced by vertical as well as horizontal Europeanization, although at differing times and to differing degrees. The UK has played a special role, developing (over several decades) support-scheme models that the Commission later partly copied in its EU-level policies. Eventually, France also came to play a somewhat similar role to the UK in EU policy developments.

While this assessment has shown that the European environment approach can offer a useful and nuanced understanding of the importance of Europeanization to domestic developments, we have thus far not examined the differences in the interrelationships between domestic and European developments across the countries, as well as the implications for domestic and EU-level policy developments. Some countries tend to be more affected by EU developments than others; and, the reverse, developments at the EU level tend to depend more on domestic developments in some countries than in others.

\section{Multi-field processes: not a zero-sum game}

As the issue of renewables-support mix has grown in importance, so has the number of fields that have influenced its development. We have noted the slight tendency for all fields to become more important over time, indicating that developments in support arrangements for renewable electricity gradually become more and more complex. Some of this can be explained by the growth in the number of instruments in the domestic support mixes, but it also results from the 
growing numbers of actors that pay attention to and have authority over the development of renewables support schemes. Juxtaposing Tables 11.1, 11.2 and 11.3 in this chapter, we see that there is no neat pattern where it is easy to identify which field is most important in each of the six case-study countries or periods. Indeed, many countries have experienced one or several periods where three fields have been significant or important at the same time.

The period after 2010 is special in the sense that the organizational field gained significance in all countries, except Sweden, and it had high impact in four out of the six countries. In Germany, the UK, France and Norway, the organizational field became far more salient than in the previous period; and in Poland, it was as important as before. Here Sweden is the deviant case, as the organizational field lost in importance. However, we cannot find any other period where one of the fields has been so clearly superior in so many countries at the same time. This seems quite puzzling, as the European environment has had at least some importance in five of the six countries in this period, and it is in EU governing mode. Moreover, after 2010, the organizational field is segmented in all fields, also in Germany and Norway, in contrast to earlier periods.

As we have limited information about the interrelationship between domestic organizational field actors and key actors at the European level, it is difficult to know what to make of this pattern. It may indicate that greater domestic segmentation helped spur the increased Europeanization that occurred in this period, including the shift in horizontal Europeanization from underpinning fixed feed-in to promoting feed-in premium combined with auctioning and greater degree of vertical EU steering. Except for Poland and Norway, the domestic organizational fields have been dominated by big electricity utilities active in many other European countries and with a strong presence in Brussels. This may have contributed to more direct relationships between utilities and EU-level actors. However, the political field was not marginalized in this period.

\section{Conclusions}

Through systematic comparative assessments, across countries and over time, in this chapter we have offered answers to our research question: what can explain the differences and similarities in renewables support mixes across countries and over time? There is no single explanatory factor that explains why some countries have ended up with largely technology-specific support mixes, and others with technology-neutral mixes. Rather, we found it essential to account for developments in multiple fields, over long stretches of time, in order to understand why two groups of countries emerged, and why the technology-specific countries became more similar over time, while the technology-neutral ones became increasingly different. Moreover, it emerged that countries sometimes end up with rather similar support schemes, for quite different reasons.

Developments in the European environment around the turn of the millennium were involved in creating a split between technology-specific Germany and France on the one hand, and technology-neutral Sweden and Norway on 
the other. By contrast, developments in the organizational field at the country level can explain why Poland and the UK came to join Germany and France, while Norway became increasingly technology-neutral. The political field proved especially important for developments in Germany and Sweden, accounting for consistencies in the approaches taken by both countries. It was the political field that ensured that Sweden retained its support mix basically unchanged, whereas Norway came to scrap its support for large-scale renewables due to developments in the organizational field.

Overall, we find that the European environment has influenced domestic support mixes less than the domestic fields. Still, it has played a crucial role for support-mix developments in all countries, especially after it shifted to EU governing mode after 2010. Domestic organizational fields are especially important when segmented, but even under such conditions, other fields are never powerless. Political fields are more prone to drive support-mix developments under conditions when the legislature governs, but they can also be important when the political field is characterized by politicization.

We have detected intriguing patterns in the relationships between multiple fields over time. Segmentation at the level of the organizational field tends to make the political field gradually less important, but this may shift if political actors succeed in politicizing an issue. In addition to developments within the political field itself, such politicization may also result from a wide range of dynamics: the broader European environment or conflicts at the level of the organizational field. We note the concurrence of EU governing and growing importance of segmented organizational fields after 2010, but we find it challenging to fully explain this pattern. However, it is clear that there is no zero-sum game between the multiple fields as regards influence. As renewables support mixes become more complex but also more important, many different fields become increasingly influential. 